\title{
PENGARUH PERTEMUAN DUA SUNGAI BATANG PASAMAN DAN BATANG KENAIKAN TERHADAP BANJIR DI MUARA KIAWAI PASAMAN BARAT
}

\author{
EFFECTS OF CROSSING BETWEEN BOTH RIVERS OF \\ BATANG PASAMAN AND BATANG KENAIKAN AGAINST \\ FLOOD AT MUARA KIAWAI IN PASAMAN BARAT
}

\author{
Chairul Nurman ${ }^{1}$, Junaidi ${ }^{2}$ dan Ahmad Junaidi ${ }^{3}$ \\ ${ }^{1,2 \text { dan } 3}$ Universitas Andalas \\ Kampus Universitas Andalas, Limau Manis, Padang \\ Email: chairulnurman@gmail.com, junaidi.joe@gmail.com dan ajunaidi55@gmail.com
}

\begin{abstract}
Naskah Masuk: 29-10-2018
Naskah Diterima:09-12-2018

Naskah Disetujui: 12-12-2018
\end{abstract}

\section{ABSTRACT}

This study examines the effect of crossing between both discharge capacity of rivers, names discharge capacity of batang pasaman river and batang kenaikan river against water level of flood that occur at muara kiawai Area in Pasaman Barat District. Discharge capacity of Rivers are simulated by using software HEC-RAS 4.1. River data using in this study is that cliffside study data on batang pasaman at Dinas PSDA West Sumatera in year 2011 those are both data of river geometry and discharge capacity of river by using the nakayatshu method with return period of flood plan of 2, 5, 10, 25, 50 and 100 yearly. Maximum High flood at scenario 1 with existing condition that involves river section of Batang Kenaikan and Batang Pasaman at upstream and downstream resulted discharge capacity of flood plan $Q$ 2 yearly $3.097 \mathrm{~m}, Q 5$ yearly $3.627 \mathrm{~m}, Q 10$ yearly $3.937 \mathrm{~m}, Q 25$ yearly $4.247 \mathrm{~m}, Q 50$ yearly $4.457 \mathrm{~m}$ and $Q$ 100 yearly $4.647 \mathrm{~m}$. Maximum Height of flood at scenario 2 with condition that only involves river section on Upstream and downstream of Batang Pasaman without river section of Batang Kenaikan resulted discharge capacity of flood plan $Q 2$ yearly $5.607 \mathrm{~m}, Q 5$ yearly $5.977 \mathrm{~m}, Q 10$ yearly $6.177 \mathrm{~m}, Q 25$ yearly $6.377 \mathrm{~m}, Q 50$ yearly $6.517 \mathrm{~m}$ and $Q 100$ yearly $6,657 \mathrm{~m}$. Maximum height of flood at scenario 3 with condition that involves river section of Batang Kenaikan and Batang Pasaman at downstream without river section of Batang Pasaman at Upstream resulted discharge capacity of flood plan $Q 2$ yearly $3.097 \mathrm{~m}, Q 5$ yearly $3.627 \mathrm{~m}, Q 10$ yearly $3.937 \mathrm{~m}, Q 25$ yearly $4.247 \mathrm{~m}, Q 50$ yearly $4.457 \mathrm{~m}$ and $Q 100$ yearly $4.457 \mathrm{~m}$. After the maximum water level of flood is obtained, it is seen that the flood happened at the crossing between of both rivers of Batang Pasaman and Batang Kenaikan at Muara Kiawai Area in Pasaman Barat District is dominated by river flow of Batang Kenaikan.

Keywords: discharge capacity of river, water level of flood, return period of flood, simulation

\begin{abstract}
ABSTRAK
Penelitian ini mengkaji tentang pengaruh dari pertemuan dua aliran debit sungai yaitu aliran debit sungai batang pasaman dan aliran debit sungai batang kenaikan terhadap ketinggian muka air banjir yang terjadi di daerah muara kiawai Kabupaten Pasaman Barat. Aliran debit sungai ini disimulasikan menggunakan software HEC-RAS 4.1. Data sungai yang digunakan dalam penelitian ini adalah data dari studi perkuatan tebing batang pasaman Dinas PSDA Sumatera Barat tahun 2011 baik data geometri sungai dan juga data aliran debit sungai dengan methoda nakayatshu periode ulang banjir rencana 2, 5, 10, 25, 50 dan 100 tahunan. Tinggi banjir maksium pada skenario 1 kondisi eksisting yaitu ruas sungai Batang Kenaikan, ruas sungai Batang Pasaman Hulu dan ruas sungai Batang Pasaman Hilir dengan debit banjir rencana Q 2 tahunan 3,097m, Q 5 tahunan 3,627m, Q 10 tahunan 3,937m, Q 25 tahunan $4,247 \mathrm{~m}$, Q 50 tahunan 4,457m dan Q 100 tahunan 4,647m. Tinggi banjir maksium pada skenario 2 kondisi tanpa ruas sungai Batang Kenaikan yaitu hanya ruas sungai Batang Pasaman Hulu dan ruas sungai Batang Pasaman Hilir dengan debit banjir rencana Q 2 tahunan 5,607m, Q 5 tahunan 5,977m, Q 10 tahunan $6,177 \mathrm{~m}$, Q 25 tahunan $6,377 \mathrm{~m}$, Q 50 tahunan $6,517 \mathrm{~m}$ dan Q 100 tahunan $6,657 \mathrm{~m}$. Tinggi banjir maksium pada skenario 3 kondisi tanpa ruas sungai Batang Pasaman Hulu yaitu hanya ruas sungai Batang Kenaikan dan ruas sungai Batang Pasaman Hilir dengan debit banjir rencana Q 2 tahunan 3,097m, Q 5 tahunan 3,627m, Q 10
\end{abstract}


tahunan 3,937m, Q 25 tahunan 4,247m, Q 50 tahunan 4,457m dan Q 100 tahunan 4,457m. Setelah tinggi muka air banjir maksimum diperoleh terlihat bahwa banjir yang terjadi pada pertemuan dua sungai Batang Pasaman dan Batang Kenaikan didaerah Muara Kiawai Kabupaten Pasaman Barat didominasi oleh aliran sungai Batang Kenaikan.

Kata Kunci: aliran debit sungai, ketinggian muka air banjir, periode ulang banjir, simulasi

\section{PENDAHULUAN}

Alih fungsi lahan yang terjadi di daerah sekitar DAS yang semula sebagai daerah resapan air berubah menjadi kawasan permukiman, perdagangan, perkebunan serta pertanian. Hal ini dapat menyebabkan kemampuan DAS untuk menahan air dibagian hulu berkurang. Sehingga seluruh air hujan akan langsung dilepaskan DAS ke arah hilir. Bahkan dengan curah hujan yang sangat tinggi dapat menyebabkan longsor di bagian hulu sungai serta penampang sungai yang mengecil tidak memadai pada suatu daerah aliran sungai akan melimpah dan mendatangkan air bah dalam volume yang besar, penggenangan akibat limpasan keluar alur sungai karena debit sungai yang membesar melampaui kapasitas aliran melanda daerah-daerah rendah permukaan bumi, di lembah, sungai-sungai, dan cekungan-cekungan sehingga berakibat terganggunya perekonomian masyarakat dan bahkan sering menimbulkan korban jiwa, yang disebut juga sebagai banjir.

Banjir dan kerusakan yang diakibatkannya adalah permasalahan yang sering melanda daerah permukiman penduduk dan prasarana infrastruktur dalam daerah hamparan sungai. hal ini terjadi pula pada Batang Pasaman, terutama di daerah sekitar Jembatan lintas Simpang Empat-Ujung Gading ke arah hulu sungai yang meliputi tiga kecamatan yaitu Kecamatan Gunung Tuleh, Kecamatan Pasaman dan Kecamatan Sasak Ranah Pesisir, dimana air sungai meluap mengenangi pemukiman, perkebunan dan membahayakan infrastruktur jembatan tersebut serta menyebabkan terganggunya jalur transportasilintas Simpang Empat-Ujung Gading.

Pada waktu banjir daya rusak sugai cukup tinggi sehingga dinamika morfologi berupa perubahan alur sungai terus terjadi dari tahun-ke tahun. Hal ini ditandai dengan perubahan alur pada sungainya hingga pemutusan meandering sungainya secara alamiah. Meandering sungai Batang Pasaman cukup banyak baik di hulu maupun di hilir jembatan hingga ke muara. Sebagian besar berada di daerah perkebunan. Kondisi Sungai seperti ini rawan terhadap kestabilan tebing sungai, melambatnya aliran banjir menuju muara, dan pelurusan alamiah alur oleh sungai itu sendiri.

Permasalahan bencana banjir beserta kerusakan yang diakibatkannyadi Batang Pasaman sering terjadi pada daerah pertemuan sungai Batang Kenaikan dengan Batang Pasaman. Kejadian banjir tersebut terjadi hampir setiap tahunnya yang dari tahun ke tahun semakin besar dan semakin sering terjadi. Kejadian banjir tersebut dapat digambarkan sebagai berikut :

- Pada Batang Pasaman, akibat curah hujan yang tinggi di hulu terjadi peningkatan aliran air secara bertahap yang kemudian tertahan oleh bukaan jembatan yang menimbulkan fenomena bottle neck di tambah dengan masuknya aliran air dari arah Batang Kenaikan. Air yang tak tertampung menggenang dan secara bertahap elevasi muka air meningkat sejalan dengan volume air yang datang. Genangan air yang terjadi meliputi daerah Muara Kiawai dan kawasan di sekitar jembatan penghubung 
Simpang Empat dan Ujung Gading tersebut.

- Adanya meandering sungai pada hilir jembatan turut memperburuk lamanya genangan.

- Terdapat daerah yang kritis pada pertemuan Batang Pasaman dengan Batang kenaikan yaitu di hulu jembatan Muara Kiawai. Hal ini dapat membahayakan jika aliran Batang Pasaman masuk ke Batang Kenaikan dan kemudian menerjang ke arah hilir dan melewati sisi Utara Abutmen Jembatan hal ini akan mengakibatkan jalan penghubung Simpang Empat dan Ujung Gading dapat terputus.

Dalam upaya melindungi kawasankawasan yang mempunyai nilai strategis dan pengaruh penting terhadap kegiatan perekonomian serta menyelamatkan infrastruktur yang ada pada kawasan rawan banjir sebagaimana yang telah diuraikan diatas, maka diperlukan suatu kajian debit banjir, dimana kajian ini kedepannya diharapkan dapat dijadikan sebagai masukan bagi pihak terkait untuk program pengendalian banjir sungai Batang Pasaman.

Adapun tujuan penelitian ini adalah untuk memprediksi tinggi muka air banjir untuk beberapa skenerio dari aliran air sungai Batang Pasaman dan Batang Kenaikan.

\section{METODOLOGI}

Metodologi tahapan penelitian merupakan langkah-langkah yang dilakukan dalam penelitian ini, seperti lokasi dilakukannya penelitian, waktu pelaksanaan, mengumpulkan data-data yang diperlukan, teknik analisis (pengolahan data) seperti uraian berikut :

\section{Lokasi Penelitian}

Penelitian ini dilakukan didaerah Nagari Muara Kiawai Kecamatan
Gunung Tuleh Kabupaten Pasaman Barat, tepatnya dipertemuan dua sungai Batang Pasaman dan Batang Kenaikan dimana didekat pertemuan tersebut terdapat jembatan penghubung antara daerah Simpang Empat dengan daerah Ujung Gading.

\section{Waktu Pelaksanaan Penelitian}

Penelitian dilaksanakan dari bulan Maret sampai dengan bulan Oktober tahun 2017.

\section{Data Debit dan Data Pengukuran}

Data-data yang digunakan adalah data Sekunder yang diperoleh dari Studi Perkuatan Tebing Batang Pasaman Dinas PSDA Sumbar tahun 2011.

- Data Debit, Sungai Batang Pasaman dan Batang Kenaikan.

- Data Pengukuran (berupa data geometri sungai), yaitu Gambar Teknis seperti Gambar Situasi, Gambar Profil Melintang, Gambar Profil Memanjang dari Sungai Batang Pasaman dan Sungai Batang Kenaikan.

\section{Data Geometri Sungai}

a. Profil melintang sungai (cross section), terdapat Data koordinat sungai $(\mathrm{X}, \mathrm{Y})$ dari masing-masing profil, di sepanjang ruas sungai lokasi studi. Pengisian data koordinat sungai dimulai dari titik awal lokasi studi di up stream hingga titik akhir di down stream dengan penomoran setiap stasiun semakin ke hilir semakin kecil.

b. Profil memanjang sungai (long section) diperoleh dengan meng-input jarak memanjang antar stasiun dari titik awal lokasi studi di up stream sampai ke titik akhir tinjauan di down stream 
sungai. Input data jarak dilakukan terhadap jarak tebing kiri, jarak tebing kanan dan jarak titik tengah sungai.

c. Koefisien kekasaran Manning (n) dasar sungai, tebing kiri dan tebing kanan sungai.

Koefisien kekasaran Manning (n) alur sungai alami yang dalam dan tanpa batuan $=0.02$ Koefisien Manning (n) untuk dataran banjir (floodplain) terdiri dari semak belukar yang tersebar \& ditumbuhi rumputan liar $=0.04$

\section{Entri Data}

Data Debit dan Data Pengukuran (gambar profil melintang dan gambar profil memanjang) Sungai Batang Pasaman dan Batang Kenaikan di entri ke software HECRAS 4.1 (Hidrologic Engineering Centre - River Analysis System).

Data aliran sungai yang menjadi bahan inputan antara lain :
a. Input data steady flow
b. Data flow hidrograph adalah data hidrograf banjir rencana inlet / Hulu.
c. Data lateral inflow hidrograph adalah data hidrograf banjir rencana Sub DAS.

\section{Simulasi Aliran}

Tujuan dari simulasi profil muka air adalah untuk mengetahui pengaruh debit yang mengalir di sungai terhadap tinggi muka air di setiap penampang sungai yang terukur.

Adapun sasaran simulasi profil muka air adalah sebagai berikut :

a. Melakukan simulasi profil muka air banjir untuk Q2, Q5, Q10, Q25, Q50 dan Q100 di ruas Bt.Pasaman Hulu dan Bt Kenaikan. b. Melakukan simulasi profil muka air banjir untuk Q2, Q5, Q10, Q25, Q50 dan Q100 di ruas Bt.Pasaman Hulu.

c. Melakukan simulasi profil muka air banjir untuk Q2, Q5, Q10, Q25, Q50 dan Q100 di ruas Bt Kenaikan.

\section{Program HEC-RAS 4.1}

Perangkat lunak (software) HECRAS 4.1 dikembangkan oleh Hydrologic Engienering Center (HEC) Amerika Serikat. HEC-RAS adalah suatu sistem perangkat lunak yang terpadu (integrated), dirancang untuk penggunanaan interaktif, multi-tasking, multi user. Sistem HEC-RAS ini terdiri dari atas Graphical User Interface (GUI), komponen analisis hidraulik, manajemen penyimpanan data serta fasilitas grafis dan pelaporan.

Secara urutan dapat ditulis sebagai berikut:

$\square$ File Management

$\square$ Tabulation and graphical displays

$\square$ Data entry and editing of input and output data

Hydraulic Analyses

$\square$ Reporting facilities

Pada HEC-RES versi 4.1 analisis hidraulika yang disediakan ialah analisis aliran permanen (steady flow). Pengaruh dari berbagai bangunan seperti jembatan, goronggorong, bendung dapat pula dimasukan pada sistem yang dibuat. Komponen ini dapat pula memodelkan aliran subkritis, superkritis mapun campuran antara keduanya.

\section{Pemodelan HEC-RAS 4.1}

Untuk kebutuhan perencananaan penanggulangan sungai rawan bencana pada Bt.Pasaman, maka analisis aspek hidraulik sungai 
sangat dibutuhkan untuk diteliti lebih cermat agar perencanaan memberikan hasil yang optimal.

Aspek hidraulik yang perlu dikaji lebih lanjut adalah sebagai berikut :

\section{$\square$ Analisis kapasitas penampang alur sungai yang ada. \\ $\square$ Analisis profil muka air banjir rencana.}

Banjir yang terjadi di daerah studi merupakan akibat dari limpasan hujan di DAS Batang Pasaman.Aliran banjir masuk secara bertahap ke alur pertemuanpertemuan sungai. Untuk mengetahui dampak luapan banjir pada debit yang sama di setiap segment sungai, digunakan pemodelan dengan jenis aliran steady flow. Model matematik yang akan digunakan dengan Software HEC-RAS 4.1. adalah pemodelan aliran permanen satu dimensi untuk analisa kapasitas sungai dalam melewatkan debit banjir rencana.

\section{Penyusunan Model}

Untuk memodelkan sistem sungai pada HEC-RAS langkah pertama dibuat adalah project. Suatu project adalah kumpulan beberapa file yang membangun model yang akan disimulasi.

Secara umum yang disiapkan untuk suatu project meliputi :

$\square$ data plan :

$$
\text { berisi kumpulan item-tem }
$$
simulasi,

data geometry aliran :

berisi antara lain

- River Reach,

- Cross section,

dan data aliran

berisi antara lain

Steady Flow,
Analisis Hidrolika (Analisis

Simulasi Aliran) Sungai dengan Pemodelan HEC-RAS 4.1

Analisis hidrolika sungai dengan menggunakan software HEC-RAS 4.1, berdasarkan data geometri sungai dan debit banjir rencana yang diperoleh pada metode analisis debit banjir. Output pemodelan sungai berupa elevasi muka air banjir untuk setiap debit rencana dan simulasi.

Sebagai langkah awal dalam analisa hidrolika adalah menentukan kondisi batas (boundary conditions) pada ruas sungai lokasi studi.

Kondisi batas tersebut adalah sebagai berikut :

1. Posisi hidrograf banjir rencana dari inlet/ Hulu (flow Hidrograph)

2. Posisi hidrograf banjir rencana dari Sub DAS lainnya di sepanjangruas sungai lokasi studi (lateral inflow)

\section{Banjir}

Dari Simulasi skenerio yang dilakukan maka akan terlihat apakah aliran yang terjadi mengalami banjir atau tidak, apabila aliran melebihi tinggi tanggul eksisting maka akan terjadi banjir dan apabila tidak melebihi tinggi tanggul eksisting maka tidak terjadi banjir.

\section{HASIL DAN PEMBAHASAN}

\section{Model Hidrolika}

Analisa hidrolika sungai dimaksudkan untuk menganalisa profil muka air banjir di sungai dengan berbagai kala ulang dari debit banjir rencana. Analisa hidrolika akan menghitung seberapa jauh pengaruh banjir terhadap tinggi muka air banjir dan luapan banjir yang terjadi. 
Perhitungan analisa hidrolika sungai dalam penulisan ini menggunakan software Hydrologic Engineering Centre-River Analysis System (HEC-RAS) versi 4.1. yang dikembangkan oleh Hydrologic Engineering Center milik U.S Army Corps of Engineers edisi November 2006.

HEC-RAS adalah system perangkat lunak terpadu dirancang untuk penggunaan interaktif dalam lingkungan multi-tugas. Sistem terdiri dari Graphic User Interface (GUI), komponen terpisah analisa hidrolik, penyimpanan data dan kapabilitas manajemen, penyimpanan data dan, fasilitas pelaporan serta grafis.

Sistem HEC-RAS mempunyai 3 komponen analisa hidrolika satu dimensi untuk :

1) Perhitungan profil permukaan air steady flow;

2) Simulasi unsteady flow; dan

3)Perhitungan transport sedimen batas yang movable.

Elemen kuncinya adalah ketiga komponen ini akan menggunakan representasi data geometrik umum dan perhitungan umum hidrolika.

Tahapan kegiatan yang dilakukan untuk analisa hidrolika adalah :

- Penyiapan skematik sungai

- Input data geometrik sungai, data debit banjir

- Perhitungan elevasi muka air banjir

Analisis output model yaitu elevasi muka air banjir untuk periode tertentu

\section{Kebutuhan data}

Kebutuhan data pada analisa hidrolika adalah data kondisi sungai berupa data geometri sungai, dan data aliran sungai (unsteady flow) berupa data debit banjir rencana dan data pasang surut.

\section{a. Geometri Sungai.}

Geometri sungai adalah:alur, palung, lembah sungai secara vertikal dan horisontal, dimana parameter yang diperlukan adalah : panjang, lebar, kemiringan, elevasi dan kekasaran. Data yang dibutuhkan untuk analisis hidrolika dikumpulkan melalui pengukuran morpologi di sepanjang sungai yang bersangkutan, data-data tersebut adalah sebagai berikut :

- Data koordinat as sungai atau tebing sungai yang ditinjau untuk menyusun skematisasi sungai.

- Posisi titik percabangan sungai dan lokasi jembatan yang ada.

- Data potongan memanjang sungai yang meliputi : jarak memanjang pada as, tebing kiri dan tebing kanan; elevasi dasar sungai, tebing kiri dan tebing kanan.

- Data cross section sungai dari muara ke arah hulu, yang diambil dari hasil pengukuran topografi sungai.

- Posisi batas palung sungai (tebing kiri dan tebing kanan) pada data cross.

- Angka kekasaran Manning (n) pada palung sungai dan bantaran sungai.

\section{b. Debit Banjir Rencana.}

Debit banjir rencanaadalah debit maksimum dari suatu sungai yang besarnya didasarkan kala ulang atau periode tertentu. Pada perhitungan hidrolika sungai, penelusuran aliran puncak dilakukan dengan kriteria bahwa : hidrograf aliran masuk untuk setiap anak sungai (lateral inflow) menggunakan hidrograf banjir dengan beberapa kala ulang. Data debit banjir rencana yang dibutuhkan adalah data yang telah dihitung pada analisa hidrologi dengan periode ulang 2, 5, 10, 25, 50 dan 100 tahun untuk setiap titik tinjauan.

Komponen Aliran dan Persamaan dalam HEC-RAS

\section{a. Aliran langgeng (Steady flow)}

Komponen pada model ini digunakan untuk menghitung profil muka air pada 
kondisi aliran langgeng (steady). Sistem ini dapat digunakan pada sebuah saluran, jaringan, atau sebuah jaringan besar termasuk saluran dan saluran kecil lainnya. Komponen pada steady flow dapat dimodelkan pada kondisi aliran subkritis, superkritis sistem gabungan profil muka air.

Dasar perhitungan komputer didasarkan pada solusi satu dimensi energi. Energi yang hilang disebabkan oleh gesekan (persamaan Manning) dan penyempitan dan pelebaran (koefisien tambahan dari perubahan dalam tinggi kecepatan). Persamaan Momentum bermanfaat dalam situasi dimana profil muka air mengalami perubahan tiba-tiba. Situasi ini termasuk dengan sistem perhitungan aliran gabungan (contoh : lompatan air) atau aliran pada jembatan dan perubahan muka air pada pertemuan saluran (arus di persimpangan).

\section{b. Aliran tidak langgeng (Unsteady flow)}

Komponen untuk aliran tidak langgeng dikembangkan untuk perhitungan aliran subkritis. Perhitungan hidrolik untuk cross-section, jembatan, gorong-gorong dan struktur hidrolik lainnya yang dikembangkan untuk komponen aliran langgeng digabung dengan perhitungan aliran tidak langgeng. Komponen untuk aliran tidak langgeng digunakan untuk model tampungan dan hubungan hidrolik dengan tampungan.

\section{c. Profil muka air pada aliran langgeng} HEC-RAS dapat melakukan perhitungan profil muka air satu dimensi untuk aliran langgeng berubah lambat laun pada saluran alami dan buatan. Subkritis, superkritis dan sistem gabungan aliran profil muka air dapat dianalisa.

\section{Kondisi Batas (Boundary Condition)}

Untuk menjalankan model maka diperlukan kondisi batas yang berguna untuk mengontrol perhitungan sehingga diperoleh hasil yang baik untuk masalah yang dihadapi. Kondisi batas yang ada di sungai terbagi atas dua yaitu kondisi batas hulu (upstream boundary condition) dan kondisi batas hilir (downstream boundary condition). Kondisi batas hulu berupa hidrograf banjir periode ulang, sedangkan kondisi batas untuk hilir berupa data Normal Depth, Critical Depth.

\section{Skenario Simulasi Muka Air}

Untuk mengetahui penyebab banjir yang terjadi di pertemuan dua sungai batang pasaman dan batang kenaikan di daerah Muara Kiawai Kabupaten Pasaman Barat dilakukan Simulasi menggunakan perangkat lunak HEC-RAS. Adapun Data Debit yang digunakan adalah Data Debit Banjir Rencana (metoda Nakayasu) yang diperoleh dari hasil perhitungan Studi Perkuatan Tebing Dinas PSDA Sumbar Tahun 2011.

\section{A. Skenario 1, Kondisi Eksisting.}

Pada Skenerio 1 ini semua sungai disimulasikan secara bersama-sama dengan debit yang dipakai adalah debit Periode Ulang 2, 5, 10, 25, 50, dan 100. Aliran dari Batang Kenaikan (Sta 198) dan aliran dari Batang Pasaman Hulu (Sta 1-142) menyatu ke Batang Pasaman Hilir (Sta 390-500). Skema dan denah hasil simulasi aliran ditunjukkan oleh Gambar 4.2 dan Gambar 4.3, serta penampang memanjang aliran yang mencakup kedalaman aliran, dasar sungai dan elevasi tebing ditunjukkan oleh Gambar 4.4, Gambar 4.5 dan Gambar 4.6. 

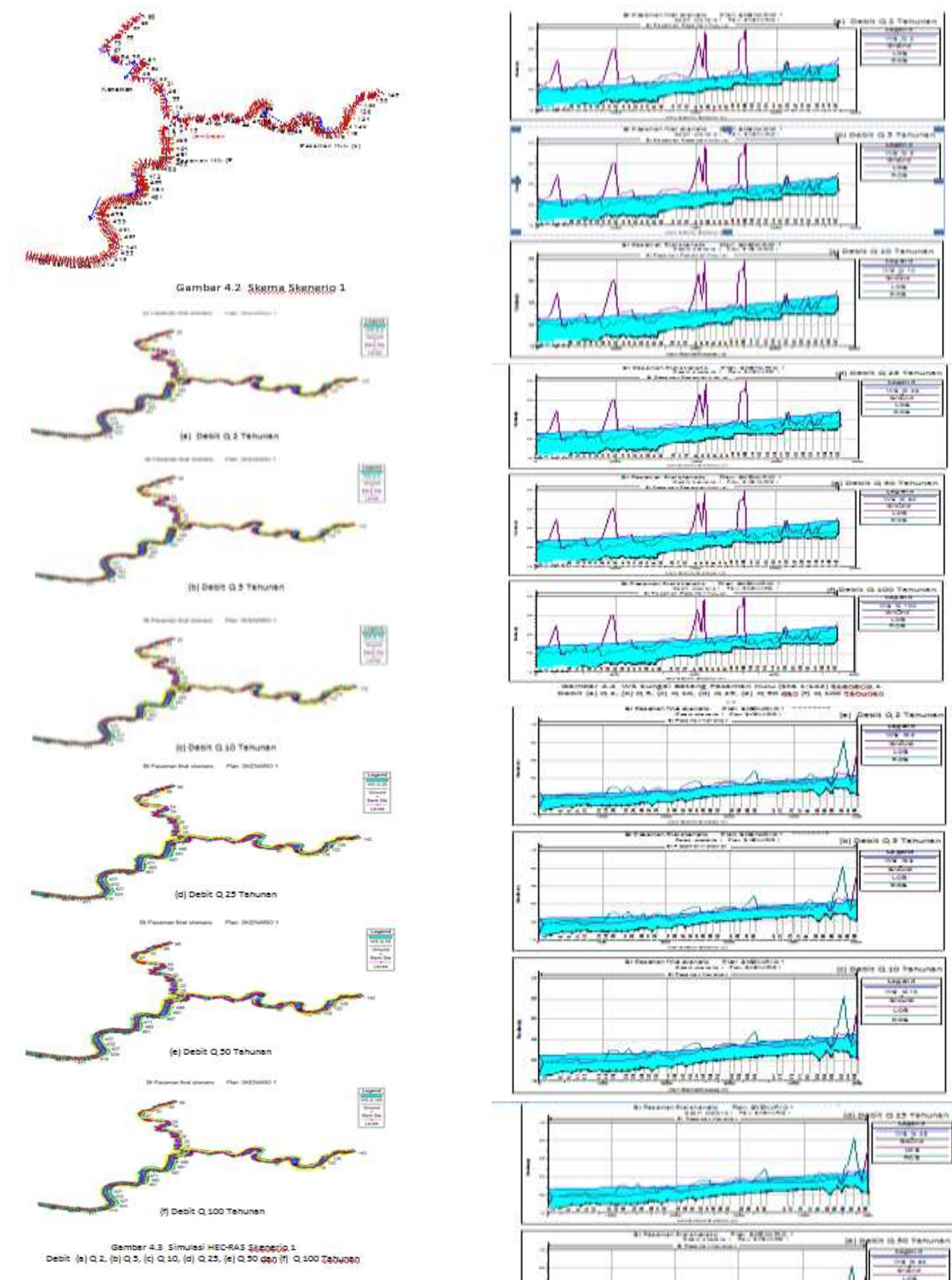

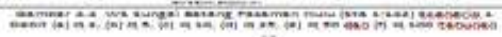
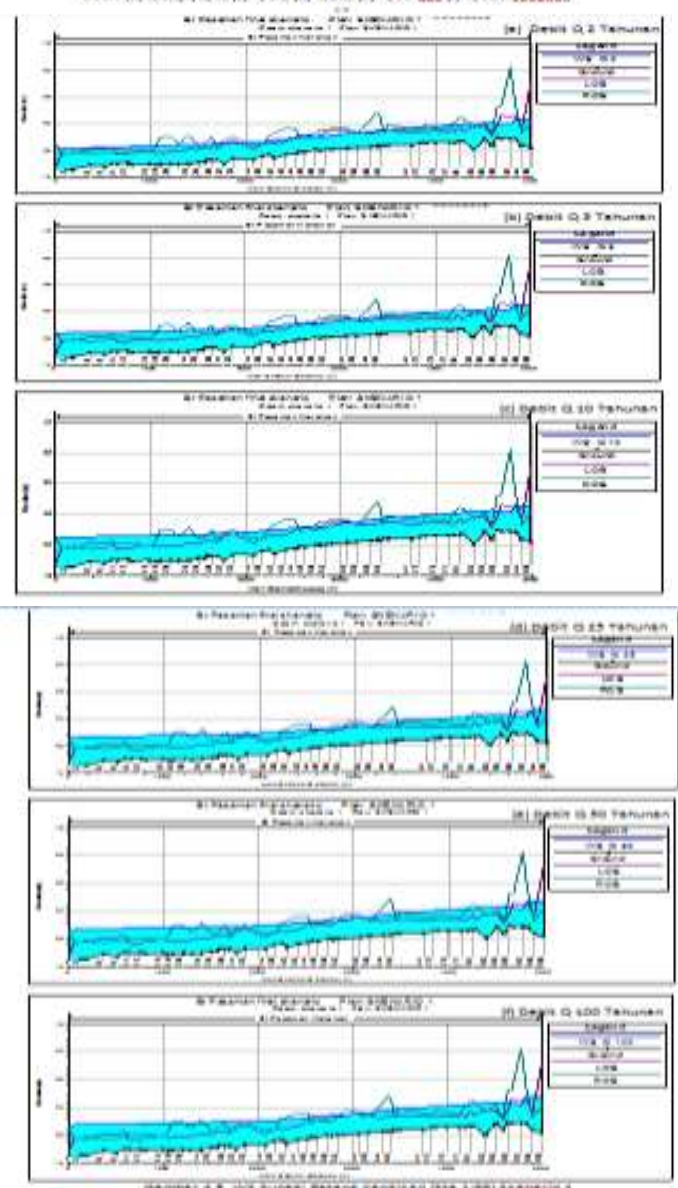

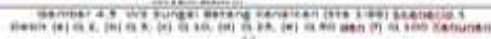



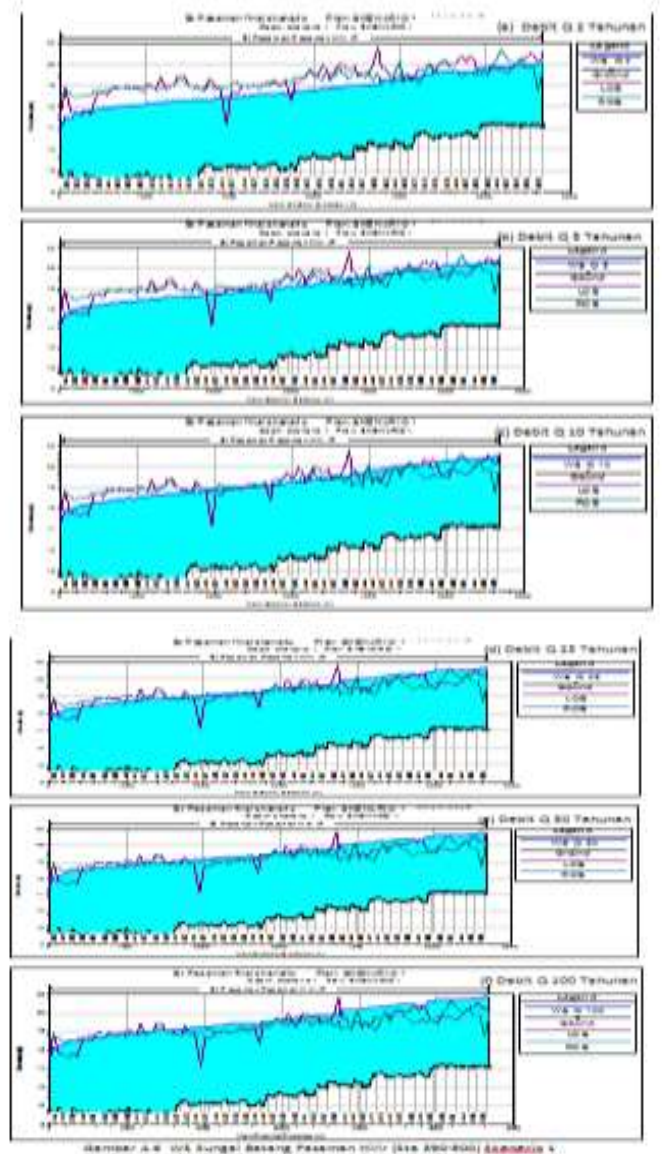

4.
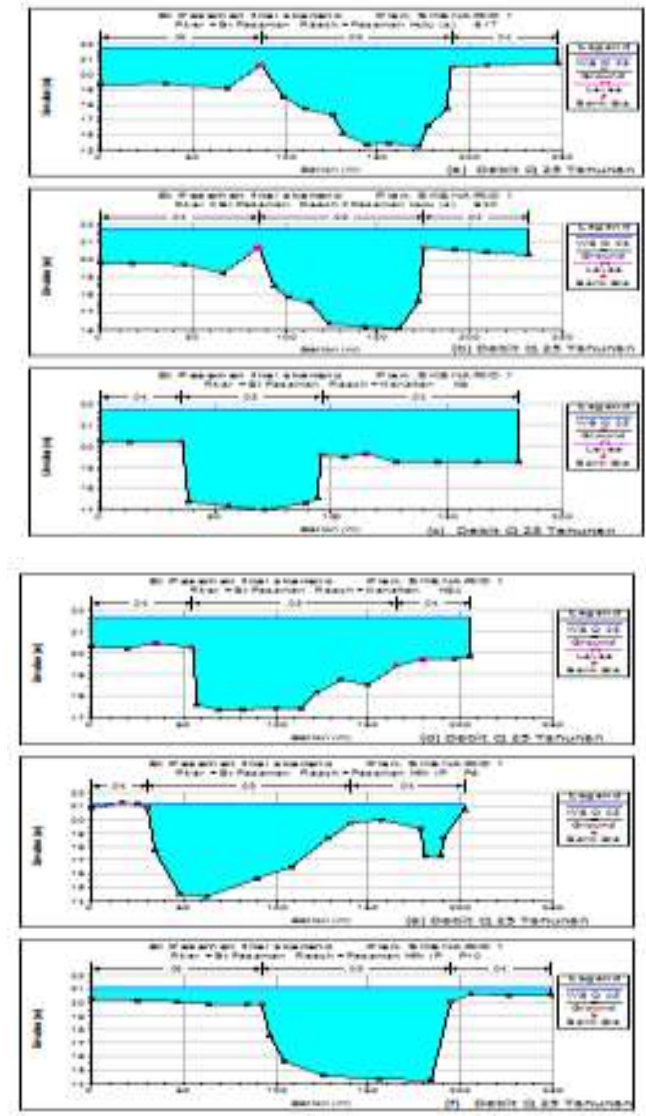

Hasil simulasi skenario 1, kondisi eksisting.

Skenario 1 dibuat untuk menggambarkan kondisi eksisting, secara bersama-sama yaitu ruas sungai Batang Kenaikan, Batang Pasaman Hulu dan Batang Pasaman Hilir, dapat dilihat pada tabel 4.1 berikut.

Tabel 4.1. Hasil Simulasi Skenerio 1, kondisi eksisting Sumber : Hasil Analisis

\begin{tabular}{|c|c|c|}
\hline Periede Clang & Titik Banjir (titik) & Tiegei Banjir Mak_(m) \\
\hline Q 2 & 175 & $3,097(\mathrm{KL})$ \\
\hline Q 5 & 206 & $3,627(\mathrm{K1})$ \\
\hline Q 10 & 228 & $3,937(\mathrm{KL})$ \\
\hline Q 25 & 249 & $4,247(\mathrm{K1})$ \\
\hline Q 50 & 259 & $4,457(\mathrm{K1})$ \\
\hline Q 100 & 271 & $4,647(\mathrm{~K} 1)$ \\
\hline
\end{tabular}

Dari hasil simulasi Skenerio 1 yang terlihat pada tabel 4.1 diatas, ruas sungai Batang Pasaman Hulu, Batang Kenaikan dan Batang Pasaman Hilir memiliki titik banjir penampang yang meluap mencapai 175 titik pada Q 2 tahunan dengan tinggi banjir maksimal hingga 3,097 $\mathrm{m}$. Banyaknya titik banjir penampang yang meluap dan tinggi banjir bertambah seiring dengan peningkatan periode ulang debit banjir.

\section{B. Skenario 2, Tanpa Ruas Sungai Batang Kenaikan.}

Pada Skenerio 2 ini Aliran Ruas Sungai Batang Kenaikan dianggap tidak ada. Debit yang dipakai adalah debit Periode Ulang 2, 5, 10, 25, 50, dan 100. Aliran dari Batang Pasaman Hulu (Sta 1-142) mengalir sampai Batang Pasaman Hilir (Sta 390-500). Skema dan denah hasil simulasi aliran ditunjukkan oleh Gambar 4.13 dan Gambar 4.14, serta penampang memanjang aliran yang mencakup kedalaman aliran, dasar sungai dan elevasi tebing ditunjukkan oleh Gambar 4.15.

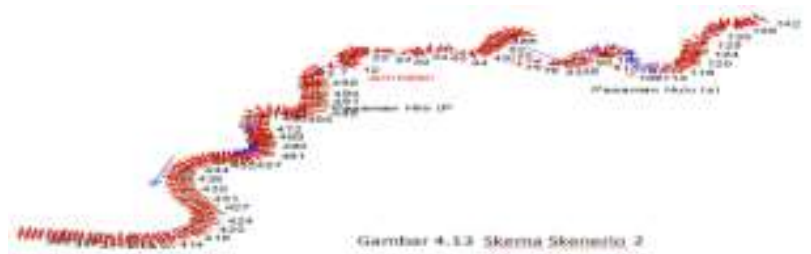



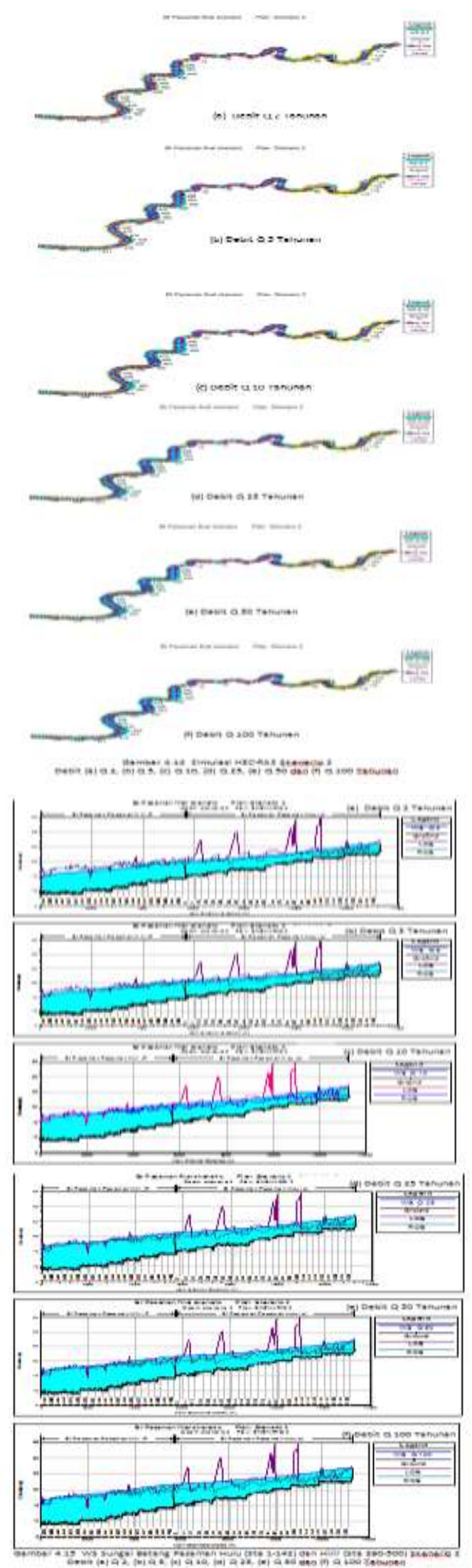
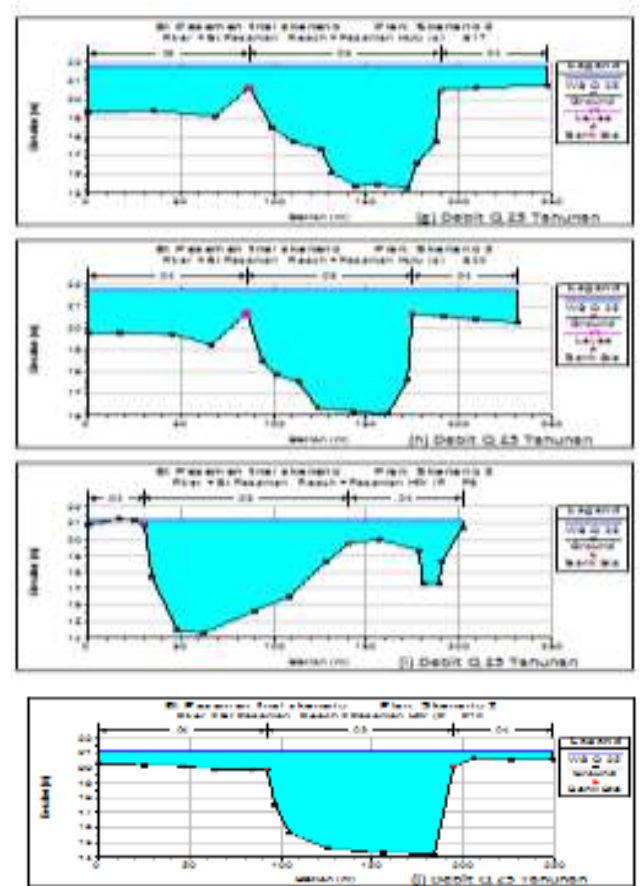

Hasil simulasi skenario 2, tanpa ruas sungai Batang Kenaikan.

Skenario 2 dibuat untuk menggambarkan kondisi tanpa ruas sungai Batang Kenaikan, hanya ruas sungai Batang Pasaman Hulu dan Batang Pasaman Hilir saja dapat dilihat pada tabel 4.2 berikut.

\begin{tabular}{|c|c|c|}
\hline Periode Ulang & Titik Banjir (titik) & Tingti Banjir Mak.(m) \\
\hline Q2 & 56 & $5,607(578)$ \\
\hline Q5 & 59 & 5,977 (\$78) \\
\hline Q 10 & 64 & 6.177 (\$78) \\
\hline Q25 & 66 & $6.377(578)$ \\
\hline Q 50 & 72 & $6,517(\$ 78)$ \\
\hline Q 100 & 83 & $6.657(578)$ \\
\hline
\end{tabular}

Dari hasil simulasi Skenerio 2 yang terlihat pada tabel 4.2 diatas, ruas sungai Batang Pasaman Hulu dan Batang Pasaman Hilir memiliki titik banjir penampang yang meluap mencapai 56 titik pada Q 2 tahunan dengan tinggi banjir maksimal hingga 5,607 $\mathrm{m}$. Banyaknya titik banjir penampang yang meluap dan tinggi banjir bertambah seiring dengan peningkatan periode ulang debit banjir rencana. 


\section{Skenario 3, Tanpa Ruas Sungai Batang Pasaman Hulu.}

Pada Skenerio 3 ini Aliran Ruas Sungai Batang Pasaman Hulu dianggap tidak ada. Debit yang dipakai adalah debit Periode Ulang 2, 5, 10, 25, 50, dan 100. Aliran dari Batang Kenaikan (Sta 1-98) mengalir sampai Batang Pasaman Hilir (Sta 390-500). Skema dan denah hasil simulasi aliran ditunjukkan oleh Gambar 4.20 dan Gambar 4.22, serta penampang memanjang aliran yang mencakup kedalaman aliran, dasar sungai dan elevasi tebing ditunjukkan oleh Gambar 4.22.
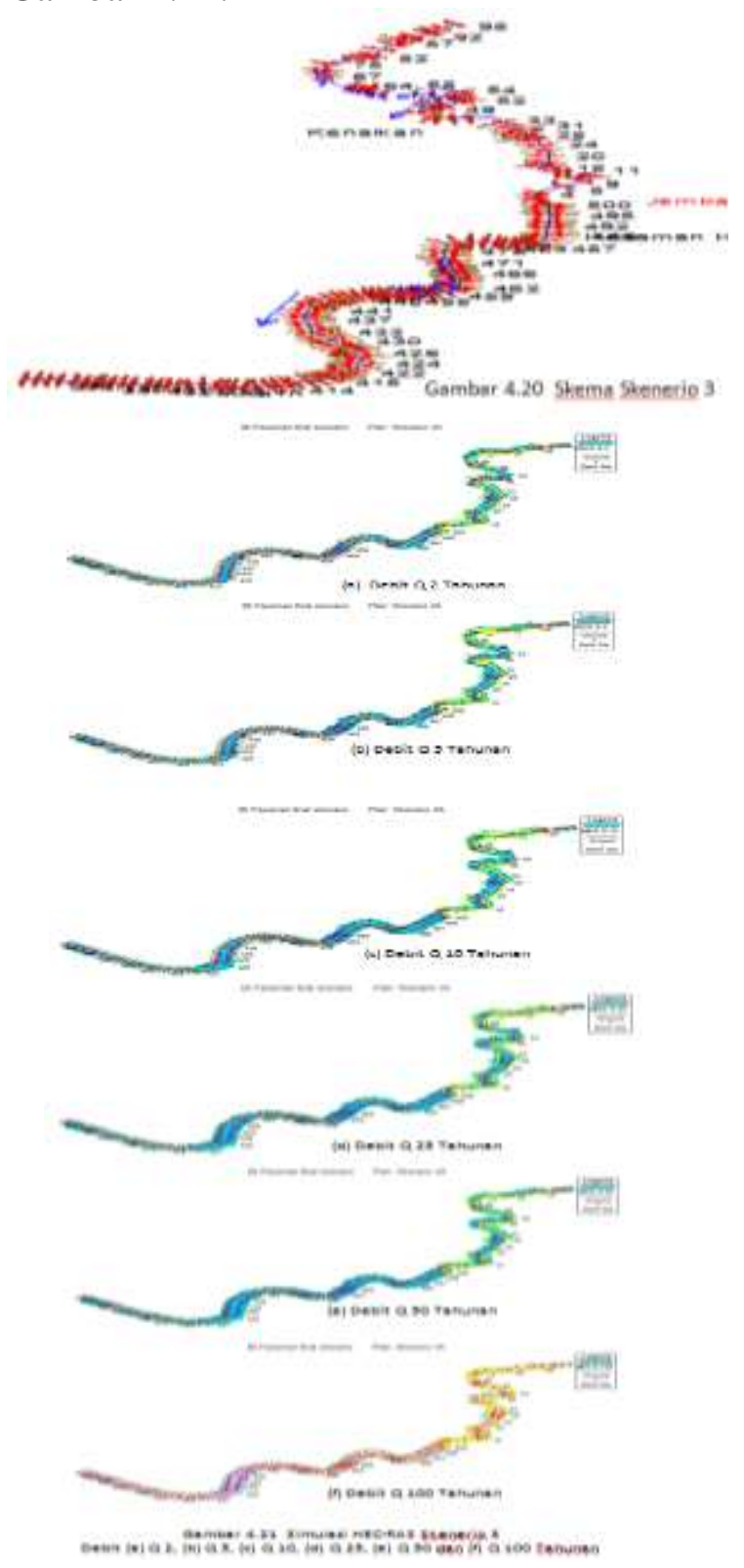
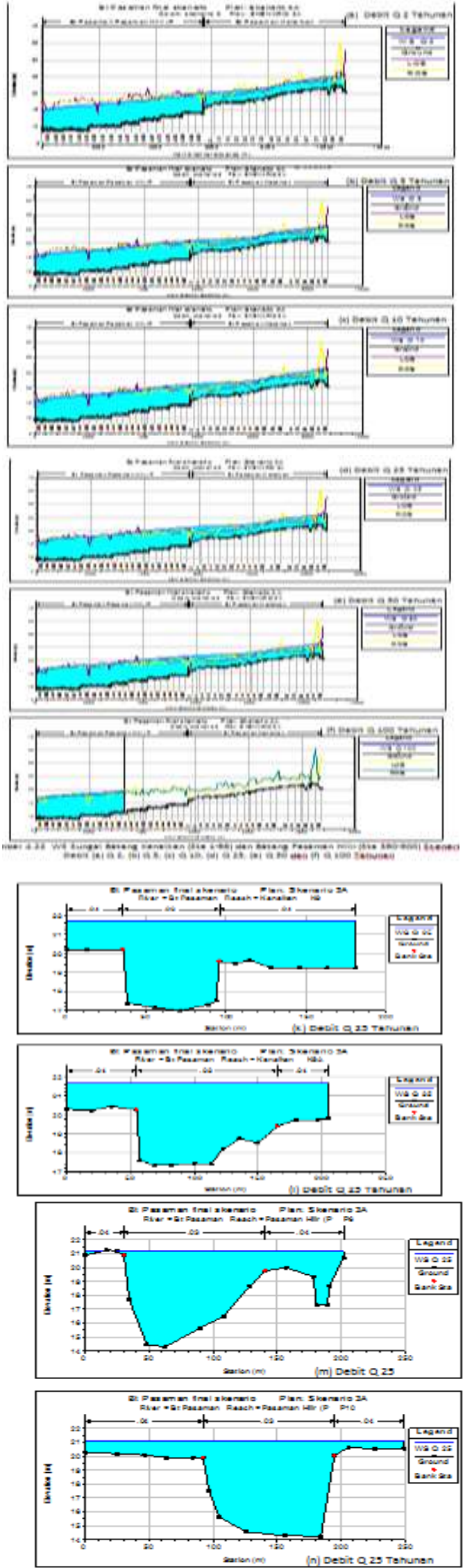

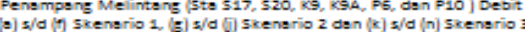


Hasil simulasi skenario 3, tanpa ruas sungai Batang Pasaman Hulu.

Skenario 3 dibuat untuk menggambarkan kondisi tanpa ruas sungai Batang Pasaman Hulu, hanya ruas sungai Batang Kenaikan dan Batang Pasaman Hilir saja dapat dilihat pada tabel 4.3 berikut.

\begin{tabular}{|c|c|c|}
\hline Prriode thas & Tinik Basjir (tink) & Tiegei Banjir Maki(m) \\
\hline Q2 & 45 & 3,097 (K1) \\
\hline Q5 & 50 & $3.627(\mathrm{~K} 1)$ \\
\hline Q 10 & 31 & 3,997 (K1) \\
\hline Q25 & 52 & $4,247(\mathrm{~K} 1)$ \\
\hline Q50 & 34 & $4.457(\mathrm{K1})$ \\
\hline Q 100 & 34 & $4,457(\mathrm{Kl})$ \\
\hline
\end{tabular}

Dari hasil simulasi Skenerio 3 yang terlihat pada tabel 4.3 diatas, ruas sungai Batang Kenaikan dan Batang Pasaman Hilir memiliki titik banjir penampang yang meluap mencapai 48 titik pada Q 2 tahunan dengan tinggi banjir maksimal hingga 3,097 m. Banyaknya titik banjir penampang yang meluap dan tinggi banjir bertambah seiring dengan peningkatan periode ulang debit banjir rencana.

\section{Resume Hasil Simulasi}

Resume hasil simulasi dari setiap skenario yaitu skenario 1, skenario 2 dan skenario 3 terlihat dalm tabel 4.4 berikut.

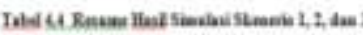

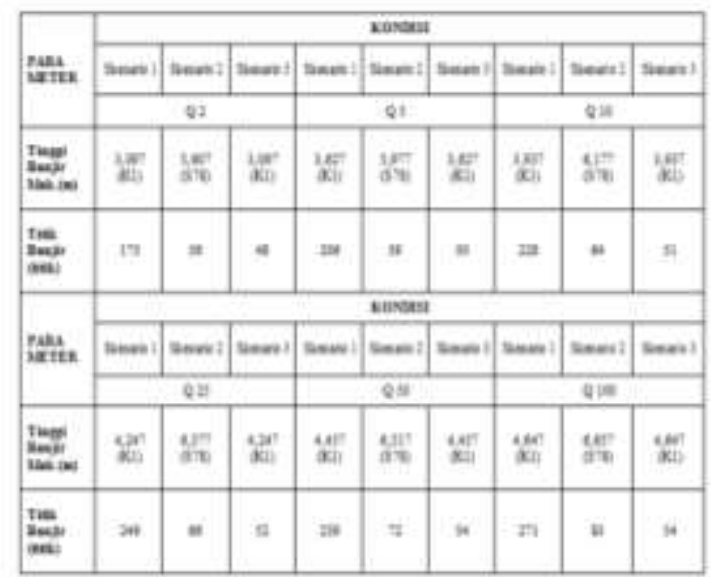

Dari apa yang telah ditampilkan didalam tabel 4.4 diatas dijelaskan bahwa, tinggi banjir maksium pada skenario 1 kondisi eksisting yaitu ruas sungai Batang Kenaikan, ruas sungai Batang Pasaman
Hulu dan ruas sungai Batang Pasaman Hilir dengan debit banjir rencana Q 2 tahunan sebesar 3,097 meter, Q 5 tahunan sebesar 3,627 meter, Q 10 tahunan sebesar 3,937 meter, Q 25 tahunan sebesar 4,247 meter, Q 50 tahunan sebesar 4,457 meter dan Q 100 tahunan sebesar 4,647 meter. Sedangkan titik banjir pada skenario 1 kondisi eksisting dengan debit banjir rencana Q 2 tahunan sebanyak 175 titik, Q 5 tahunan sebanyak 206 titik, Q 10 tahunan sebanyak 228 titik, Q 25 tahunan sebanyak 249 titik, Q 50 tahunan sebanyak 259 titik dan Q 100 tahunan sebanyak 271 titik.

Tinggi banjir maksium pada skenario 2 kondisi tanpa ruas sungai Batang Kenaikan yaitu hanya ruas sungai Batang Pasaman Hulu dan ruas sungai Batang Pasaman Hilir dengan debit banjir rencana Q 2 tahunan sebesar 5,607 meter, Q 5 tahunan sebesar 5,977 meter, Q 10 tahunan sebesar 6,177 meter, Q 25 tahunan sebesar 6,377 meter, Q 50 tahunan sebesar 6,517 meter dan Q 100 tahunan sebesar 6,657 meter. Sedangkan titik banjir pada skenario 2 kondisi kondisi tanpa ruas sungai Batang Kenaikan dengan debit banjir rencana Q 2 tahunan sebanyak 56 titik, Q 5 tahunan sebanyak 59 titik, Q 10 tahunan sebanyak 64 titik, Q 25 tahunan sebanyak 66 titik, Q 50 tahunan sebanyak 72 titik dan Q 100 tahunan sebanyak 83 titik.

Tinggi banjir maksium pada skenario 3 kondisi tanpa ruas sungai Batang Pasaman Hulu yaitu hanya ruas sungai Batang Kenaikan dan ruas sungai Batang Pasaman Hilir dengan debit banjir rencana Q 2 tahunan sebesar 3,097 meter, Q 5 tahunan sebesar 3,627 meter, Q 10 tahunan sebesar 3,937 meter, Q 25 tahunan sebesar 4,247 meter, Q 50 tahunan sebesar 4,457 meter dan Q 100 tahunan sebesar 4,457 meter. Sedangkan titik banjir pada skenario 3 kondisi tanpa ruas sungai Batang Pasaman Hulu dengan debit banjir rencana Q 2 tahunan 
sebanyak 48 titik, Q 5 tahunan sebanyak 50 titik, Q 10 tahunan sebanyak 51 titik, Q 25 tahunan sebanyak 52 titik, Q 50 tahunan sebanyak 54 titik dan Q 100 tahunan sebanyak 54 titik.

Setelah tinggi muka air banjir maksimum diperoleh terlihat bahwa banjir yang terjadi pada pertemuan dua sungai Batang Pasaman dan Batang Kenaikan didaerah Muara Kiawai Kabupaten Pasaman Barat didominasi oleh aliran sungai Batang Kenaikan.

\section{KESIMPULAN}

Hasil penelitian yang dilakukan mengenai simulasi aliran debit banjir rencana menggunakan software HEC-RAS 4.1 dengan 3 alternatif skenario untuk memprediksi tinggi muka air banjir dari pengaruh pertemuan dua sungai Batang Pasaman dan Batang Kenaikan adalah sebagai berikut ;

\section{Skenerio 1}

Skenario 1 dibuat untuk menggambarkan kondisi eksisting dari ketiga ruas sungai Batang Pasaman Hulu, Batang Kenaikan dan Batang Pasaman Hilir. Hasil simulasi skenario 1. Tinggi banjir maksium dengan debit banjir rencana Q 2 tahunan sebesar 3,097 meter, Q 5 tahunan sebesar 3,627 meter, Q 10 tahunan sebesar 3,937 meter, Q 25 tahunan sebesar 4,247 meter, Q 50 tahunan sebesar 4,457 meter dan Q 100 tahunan sebesar 4,647 meter. Sedangkan titik banjir pada skenario 1 kondisi eksisting dengan debit banjir rencana Q 2 tahunan sebanyak 175 titik, Q 5 tahunan sebanyak 206 titik, Q 10 tahunan sebanyak 228 titik, Q 25 tahunan sebanyak 249 titik, Q 50 tahunan sebanyak 259 titik dan Q 100 tahunan sebanyak 271 titik..

\section{Skenerio 2}

Skenario 2 dibuat untuk menggambarkan kondisi tanpa ruas sungai Batang Kenaikan, hanya ruas sungai Batang Pasaman Hulu dan Batang Pasaman Hilir. Hasil simulasi skenario 2. Tinggi banjir maksium dengan debit banjir rencana Q 2 tahunan sebesar 5,607 meter, Q 5 tahunan sebesar 5,977 meter, Q 10 tahunan sebesar 6,177 meter, Q 25 tahunan sebesar 6,377 meter, Q 50 tahunan sebesar 6,517 meter dan Q 100 tahunan sebesar 6,657 meter. Sedangkan titik banjir pada skenario 2 kondisi kondisi tanpa ruas sungai Batang Kenaikan dengan debit banjir rencana Q 2 tahunan sebanyak 56 titik, Q 5 tahunan sebanyak 59 titik, Q 10 tahunan sebanyak 64 titik, Q 25 tahunan sebanyak 66 titik, Q 50 tahunan sebanyak 72 titik dan Q 100 sebanyak 83 titik.

\section{Skenerio 3}

Skenario 3 dibuat untuk menggambarkan kondisi tanpa ruas sungai Batang Pasaman Hulu, hanya ruas sungai Batang Kenaikan dan Batang Pasaman Hilir. Hasil simulasi skenario 3. Tinggi banjir maksium dengan debit banjir rencana Q 2 tahunan sebesar 3,097 meter, Q 5 tahunan sebesar 3,627 meter, Q 10 tahunan sebesar 3,937 meter, Q 25 tahunan sebesar 4,247 meter, Q 50 tahunan sebesar 4,457 meter dan Q 100 tahunan sebesar 4,457 meter. Sedangkan titik banjir pada skenario 3 kondisi tanpa ruas sungai Batang Pasaman Hulu dengan debit banjir rencana Q 2 tahunan sebanyak 48 titik, Q 5 tahunan sebanyak 50 titik, Q 10 tahunan sebanyak 51 titik, Q 25 tahunan sebanyak 52 titik, Q 50 tahunan sebanyak 54 titik dan Q 100 sebanyak 54 titik.

4. Setelah tinggi muka air banjir maksimum diperoleh terlihat bahwa banjir yang terjadi pada pertemuan dua sungai Batang Pasaman dan 
Batang Kenaikan didaerah Muara Kiawai Kabupaten Pasaman Barat didominasi oleh aliran sungai Batang Kenaikan

\section{REKOMENDASI}

Dari hasil penelitian yang dilakukan dapat diusulkan beberapa saran untuk penelitian lanjutan dalam pengelolaan dan penanggulangan pengendalian banjir dipertemuan dua sungai Batang Pasaman dan Batang Kenaikan di daerah Muara Kiawai Kabupaten Pasaman Barat, adalah sbb ;

1. Pada penelitian ini skenario yang dilakukan masih sedikit, disarankan pada penelitian lanjutan skenario yang dilakukan lebih komplek

\section{DAFTAR PUSTAKA}

Bambang Subyandono. 2007, Diktat Kuliah Teknik Persungaian, Bambang Subyandono, Jakarta.

Chow Ven Te. 1992, Hidrolika Saluran Terbuka, Erlangga, Jakarta.

Ginting, H Segel. Materi Pelatihan Pedoman Hidraulik Aliran dengan HEC-RAS, Segel Hendrycus Ginting, Bandung.

Hydrologic EngineeringCenter. 2006, HEC-RASRiver Analysis System, , U.S. Army Corps of Engineers, USA.

Istiarto. 2014, Simulasi Aliran 1-Dimensi Dengan Bantuan Paket Program Hidrodinamika HEC-RAS Jenjang Dasar SimpleGeometry River, Penerbit, Jogjakarta.

Kodoatie, R.J., Sugiyanto. 2002, Banjir (Beberapa Penyebab dan Metode Pengendaliannya dalam Perspektif sehingga yang dihasilkan akan lebih baik.

2. Pada penelitian lanjutan yang dilakukan oleh peneliti lainnya, disarankan variabel yang digunakan sebaiknya beragam seperti variable sedimen transport dan adanya aliran debris, variable perubahan penampang akibat pengikisan pada lokasi penelitian.

3. Pada penelitian lanjutan disarankan melakukan kombinasi skenerio dengan penanganan seperti pembuatan tanggul dan juga disarankan menggunakan aliran tidak tetap unsteady flow sehingga proses banjir dapat terlihat seiring waktu.

Lingkungan), Pustaka Pelajar, Yogyakarta.

Linsley Jr, R.K., dkk. 1996, Hidrologi untuk Insinyur, Erlangga, Jakarta.

Mas Mera. 2011, Rekayasa Hidrologi, Feria. Padang.

Mulyanto. 2007, Sungai, Fungsi dan Sifat-sifatnya, Penerbit Graha Ilmu, Yogyakarta.

Soemarto, C.D. 1999, Hidrologi Teknik, Erlangga, Jakarta.

Soewarno. 1991, Hidrologi Pengukuran dan Pengolahan Data Aliran Sungai Hidrometri, Penerbit Nova, Bandung.

Soewarno. 1995, Hidrologi Aplikasi Metode Statistik untuk Analisia Data, Penerbit Nova, Bandung.

Sosrodarsono, S., Masateru, T. 1985, Perbaikan dan Pengaturan Sungai, PT Pradnya Paramita, Jakarta. 